DIW BERLIN

Discussion

Papers

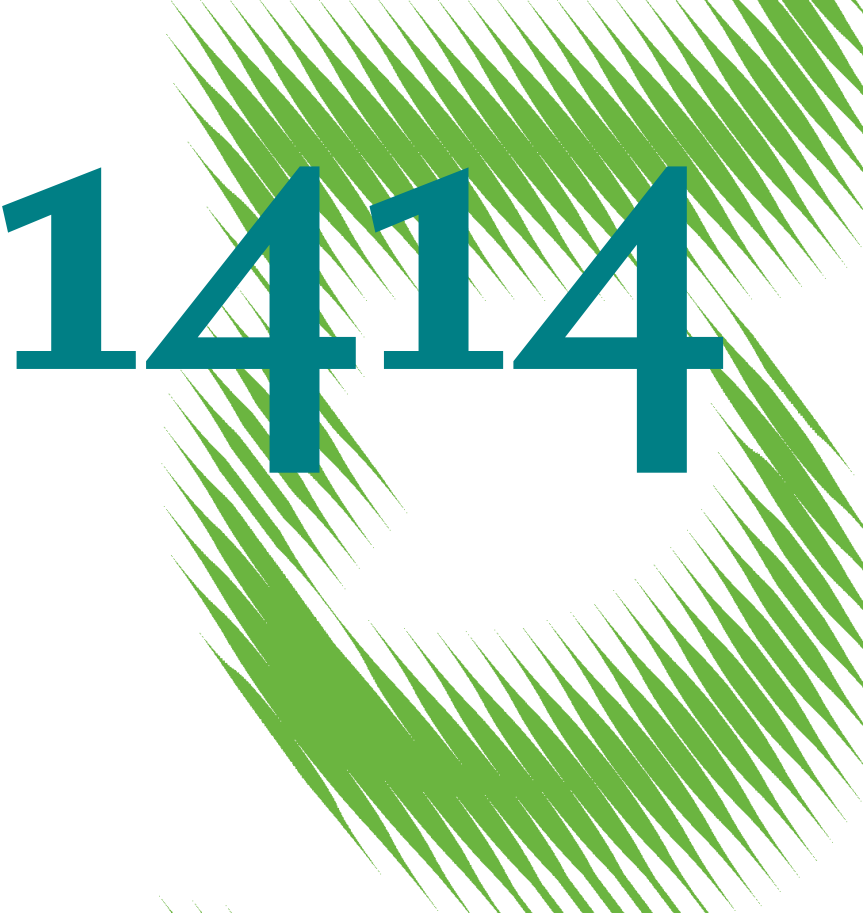

Filtering German Economic Conditions from a Large Dataset: The New DIW Economic Barometer 
Opinions expressed in this paper are those of the author(s) and do not necessarily reflect views of the institute.

IMPRESSUM

(C) DIW Berlin, 2014

DIW Berlin

German Institute for Economic Research

Mohrenstr. 58

10117 Berlin

Tel. +49 (30) $89789-0$

Fax +49 (30) $89789-200$

http://www.diw.de

ISSN electronic edition 1619-4535

Papers can be downloaded free of charge from the DIW Berlin website:

http://www.diw.de/discussionpapers

Discussion Papers of DIW Berlin are indexed in RePEc and SSRN:

http://ideas.repec.org/s/diw/diwwpp.html

http://www.ssrn.com/link/DIW-Berlin-German-Inst-Econ-Res.html 


\title{
Filtering German Economic Conditions from a large Dataset: the new DIW Economic Barometer*
}

\author{
Paul Viefers ${ }^{\dagger} \quad$ Ferdinand Fichtner ${ }^{\ddagger} \quad$ Simon Junker ${ }^{\S}$ \\ Maximilian Podstawski $₫$
}

30th September 2014

\begin{abstract}
This paper presents a revised version of the DIW Economic Barometer, the business cycle index of the German Institute for Economic Research (DIW Berlin). As in earlier versions, we put forward a factor model on a monthly frequency to filter the latent state of the aggregate economy. In the new version, the resulting business cycle factor is based on more than 300 variables. The main methodological changes relate to (i) the estimation procedure, (ii) treatment of publication lags and missings, and (iii) the decomposition of the index into contributions from different sectors of the economy. Alongside several practical advantages, we also document a better historical nowcasting performance of the new index.
\end{abstract}

JEL-Classification: E32; E37

Keywords: Business Cycles, Nowcasting, Dynamic Factor Models, Principal Components.

${ }^{*}$ We would like to thank Thore Schlaak for excellent research assistance.

${ }^{\dagger}$ DIW Graduate Center, Mohrenstr. 58, D-10117 Berlin, Germany (email: pviefers@diw.de).

${ }^{\ddagger}$ DIW Berlin, Department of Forecasting and Economic Policy, Mohrenstr. 58, D-10117 Berlin, Germany (email: ffichtner@diw.de).

${ }^{\S}$ DIW Berlin, Department of Forecasting and Economic Policy, Mohrenstr. 58, D-10117 Berlin, Germany (email: sjunker@diw.de).

ॠDIW Berlin, Department of Forecasting and Economic Policy, Mohrenstr. 58, D-10117 Berlin, Germany (email: mpodstawski@diw.de). 


\section{Nicht-technische Zusammenfassung}

Die zeitnahe Bewertung der konjunkturellen Lage ist von zentraler Bedeutung für Wirtschafts- und Finanzmarktakteure und politische Entscheidungsträger. Nicht nur in der historischen Betrachtung gehört eine solche Bewertung zu den Kernaufgaben des Deutschen Instituts für Wirtschaftsforschung (DIW Berlin). Vor diesem Hintergrund stellte das DIW Berlin im Jahr 2003 das DIW Konjunkturbarometer vor, das seither monatlich veröffentlicht wird und sich als eine eigene Marke etabliert hat. Das vorliegende Diskussionspapier dokumentiert eine methodische Überarbeitung des DIW Konjunkturbarometers. Dabei erweitert die neue Version des DIW Konjunkturbarometers die vorherige entlang verschiedener Dimensionen.

Die neue Version des Barometers basiert auf einem deutlich vergrößerten Datensatz von mehr als 300 Variablen aus unterschiedlichen Quellen und vergrößert die Datengrundlage gegenüber der vorherigen Version damit um das Fünffache. Auf der Basis dieses großen Datensatzes bedient sich die Neuauflage des DIW Konjunkturbarometers der Methodik des Faktormodells und führt damit methodisch die grundlegende Struktur der vorherigen Version des Konjunkturbarometers fort. Diese Modellklasse wird häufig für Kurzfristprognosen eingesetzt und modelliert die konjunkturelle Lage als unbeobachtbare Größe, die sich aus dem Zusammenhang und der Dynamik in den zugrundliegenden Daten ergibt. Damit erfüllt das DIW Konjunkturbarometer eine der zentralen Anforderungen an ein solches Prognoseinstrument und liefert über die Zeit stabile Einschätzungen der gesamtwirtschaftlichen Lage auf der Grundlage einer robusten und bewährten Methodik.

Eine für die Prognosepraxis wichtige Neuerung ist die Möglichkeit fehlende Beobachtungen, bspw. auf Grund von Zeitverzögerungen bei der Veröffentlichung von Daten (sog. 'ragged edges'), systematisch aufzufüllen. Dies geschieht über den geschätzten Zusammenhang zwischen den jeweiligen Variablen und den Daten im Datenblatt: Der Algorithmus mit dem das Modell geschätzt wird, iteriert wiederholt zwischen (i) dem Filtern der konjunkturellen Gesamtlage einerseits und (ii) dem Schätzen fehlenden Beobachtungen auf Basis der Gesamtlage andererseits. Gegeben, dass die Zeitverzögerungen je nach Variable teils erheblich und zugleich sehr heterogen sind, ist diese Neuerung von großer praktischer Relevanz.

Desweiteren ermöglicht die hier vorgestellte Neuauflage des Barometers über die Bewertung der gesamtwirtschaftlichen Situation hinaus eine sektorale Analyse der Konjunkturlage. Zwar ist die Bereitstellung eines einzelnen Indexwertes als Maß für die konjunkturelle Situation zu jedem Zeitpunkt sinnvoll und hilfreich, weil sie eine Fülle an Information in eine Zahl verdichtet. Für sich betrachtet lässt jedoch ein solcher Index weitergehende Fragen, wie zum Beispiel nach den (sektoralen) Treibern der konjunkturellen Entwicklung, offen. Wir verwenden daher ein zweistufiges Verfahren. Auf der ersten Stufe teilen wir unsere Variablen in Gruppen auf, bspw. Variablen zur Industrieproduktion, oder zur Entwicklung im Dienstleistungssektor und filtern separate Indizes aus jeder dieser Gruppen. Auf der zweiten Stufe nehmen wir die Indizes der ersten Stufe und extrahieren aus ihnen einen gemeinsamen Gesamtindex: das DIW Konjunkturbarometer. Dies ermöglicht uns die Beiträge jeder Gruppe zum Gesamtindex in Form von Indexpunkten zu berichten. Die Information über die Beiträge einzelner Variablen oder Gruppen von Variablen zum Faktorwert lässt sich den Ansprüchen des Prognostikers gemäß (dis-)aggregieren und ermöglicht es in die zugrundliegenden 
Daten hinein- und hinauszuzoomen.

Schließlich bricht die neue Version des DIW Konjunkturbarometer mit dem Vorgehen des vorherigen Barometers darin, dass es nicht mehr explizit das BIP als Zielgröße ansteuert. Dies hat zwei Gründe. Zum einen soll der ausschließlich datengetriebene Index für die Punktprognose einer Wachstumszahl durch weicheres, einem quantitativen Modell kaum zugängliches Expertenwissen ergänzt werden. Zum anderen führt die Berücksichtigung des Bruttoinlandsprodukts im Datensatz des Barometers aufgrund der Modellstruktur zu einem Zirkelschluss. Das BIP würde innerhalb des Modells zum Index beitragen und später aus dem Index, und damit formal in Teilen von sich selbst getrieben und prognostiziert werden.

Der Ansatz des neuen DIW Konjunkturbarometers ist nicht nur eine konzeptionelle Weiterentwicklung, sondern geht auch mit einer signifikanten Verbesserung der Prognosegüte, insbesondere im ersten Monat eines Quartals, einher. Das zeigt der Vergleich mit der vorherigen Version des DIW Konjunkturbarometers und einigen anderen Prognosemodellen in Pseudo-Echtzeit. Zudem verweist die rekursive Schätzung in Pseudo-Echtzeit auf die große Stabilität des Modells, die auch von extremen konjunkturellen Ereignissen, wie der Weltwirtschaftskrise von 2009, nicht maßgeblich beeinträchtigt wird. 


\section{Non-Technical Summary}

The timely assessment of aggregate business cycle conditions is of great interest for much of the business and financial world, as well as for policy makers and historically one of the main tasks of the German Institute for Economic Research (DIW Berlin). Against this background, the DIW Berlin launched the DIW Economic Barometer in 2003. This paper puts forward and presents a new edition of the DIW Economic Barometer, which mainly comes in form of a major methodological overhaul. It describes the main differences to the former edition and presents features of the new index, which replaces the former.

The first change relates to the size of the data set. While the previous edition employed roughly 60 variables, we use more than 300 variables in the new edition. In terms of methodological changes, our focus was to develop a new edition that produces stable inference with a well-established methodology that has proven to work well in practice. We therefore continue to use a factor model to construct the index. These models define business conditions as an unobservable variable, which is about the comovements of many variables. We thus filter it from a large set of variables. Factor models are widely used in economics and especially in the field of nowcasting.

One feature of the new methodology that is particularly relevant in practice is the systematic handling of missing observations, e.g. due to publication lags ('ragged edges'). Given the sizable variation of publication lags in our data set, this feature is of particular importance. The estimation procedure iterates until convergence between (i) estimating the common component of the observable data and (ii) constructing estimates of the missing observations.

Another important change relates to how the index is presented. First, while the provision of a single, comprehensive figure is desirable because it condenses information into a single number, it alone misses to provide an indication where movements in the index stem from. We therefore employ a two-stage procedure. At the first stage, we group variables in our data set into several clusters, e.g. variables related to the industrial sector, and extract common factors from each group. At the second stage, we extract a single common factor - the index - from the collection of first-stage factors. Together with the final index, we are then able to report the amount of index points each group of first-stage factors contributed. The depth of the information provided by such a decomposition is easily adjustable by the nowcaster and makes it convenient to 'zoom in and out' into the data.

Finally, it is important to note that the index does not explicitly target a point estimate of GDP. This is for two reasons. On the one hand we still want to leave space for discretionary action by the nowcaster, who has not only the data set of the model but additional 'softer' information at hands. On the other hand, including quarterly GDP as target variable in the model introduces circularity, as GDP would load on GDP and thus nowcast itself.

Results from a pseudo real-time GDP now- and forecasting exercise show that the new approach is not only conceptually superior, but also produces significantly more accurate nowcasts as compared to a number of competitors, including the former version of the DIW Economic Barometer and that inference is stable and reliable, also surrounding extreme events such as the recession in 2009. 


\section{Introduction}

The timely assessment of aggregate business conditions is of great interest for much of the business and financial world, as well as for policy makers. All economic agents have to make their decisions in real-time and ideally base such decisions on an informed, timely and precise measurement of the current stance of the economic cycle. To inform the public and to provide such a timely measurement is one of the key tasks of many public service institutions (governmental or nongovernmental) around the world, and historically one of the main tasks of the German Institute for Economic Research (DIW Berlin, DIW henceforth). ${ }^{1}$

While the institute published business cycle reports on a regular basis already in 1926, it was in 2003 when it first presented the DIW Economic Barometer (DIW Konjunkturbarometer, henceforth simply 'the index') - a business cycle index for Germany published together with a nowcast for the current quarterly GDP growth rate. This paper briefly discusses the methodology behind the former edition of the index and puts forward the new edition of the DIW Economic Barometer. It describes the main methodological differences and features of the new index, which replaces the former.

There were several requirements for the new edition, mainly in response to the experience gathered over the years with the first edition. Hence, our focus was less to max out the current research frontier, but more to develop a model which tackles these open issues and produces reliable inference using a well-established, much-tested methodology, that has proven to work well in practice. First, there was the intention to base the index on a much larger data set, and thus to include information the former data set was missing out. Consequently, we required a model that is able to handle large data sets. At the same time, a transparent and parsimonious model was desired. Second, we wanted the model to be reliable and to deliver stable inference over time, i.e. a model that captures well the gradual evolution of the business cycle. In line with the previous edition, the model was to be based on a monthly frequency to provide a timely assessment of the business cycle. To maintain the desired smoothness of the index at the same time, however, poses a challenge to the modeler, because the underlying series are much more erratic at the monthly frequency than at the quarterly frequency. Hence, it was an imperative to reach a sweet spot between filtering out noise and not loosing too much information. Third, we wanted to handle publication lags and missing observations in a conceptually clean way within the model framework. Fourth, it was a requirement that the resulting index would be reasonably precise in nowcasting GDP growth, even though we did not explicitly make GDP our target variable. Fifth, we wanted the model not only to provide a single figure - the index - but also some insight into the (sectoral) drivers of the current value of the index.

As already mentioned, the first noticeable change relative to the previous edition is that we employ a much larger data set. The previous edition was based on a data set with less than 60 series. With

\footnotetext{
${ }^{1}$ When the economist Ernst Wagemann founded the institute in 1925, this was not only embodied in its former name Deutsches Institut für Konjunkturforschung (German Institute for Business Cycle Research), but it is also stipulated in the institute's agenda, where it says that one of the institute's main purposes is: “(...) to collect and disseminate the necessary material to gauge the current stance of the business cycle."(see Krengel, 1986).
} 
the new edition we extend the data set to contain more than 300 variables from several sources. In terms of the modeling paradigm, we follow the previous edition of the index and use a factor model. Factorization is a well-established methodology to summarize common movements and central tendencies in large data sets and are widely used for nowcasting (Geweke, 1977; Sargent and Sims, 1977; Chamberlain and Rothschild, 1983; Stock and Watson, 1989b,a, 2006). Hence, this provided us with the required reliability and track record in practice. Another salient feature of factor models is that they provide a parsimonious way to filter the common comovements among a very large set of variables. The way factor models achieve this is conceptually very transparent: the resulting index is a weighted average of all variables at each point in time, where the weights are chosen such that the index covers the maximal share of the overall variation across all series. The second change relates to the specificities of the underlying model. The new edition largely builds on the work by Schumacher and Breitung (2008). While they focus on filtering and forecasting monthly latent GDP, their general model setup (which in turn builds on work by Stock and Watson, 1989a, 2006) provides us with a way to tackle a problem of great practical importance: publication lags ('ragged edges') and missing observations. Given the sizable variation of publication lags in our data set, ranging from being immediately available in real-time (financial data) to several months behind (industrial production), this feature is of particular importance. The estimation procedure we employ iterates until convergence between (i) estimating the common component of the observable data and (ii) constructing estimates of the missing observations.

Although our fundamental approach follows Schumacher and Breitung (2008), we deviate from their model along two dimensions. First, while the provision of a single, comprehensive index is surely the prime feature of factor models, the index alone misses to provide an answer to the question where movements in the index stem from. That is, while a single figure is desirable, it is of great interest to identify the variables (or group of variables) that drive the movements of the factor at the current edge, i.e. their individual contributions to the common factor. A decomposition at the level of the individual variable would nullify the complexity-reducing feature of our model, however. We therefore strike a balance between being overly simplistic and completely unraveling the dimension reduction. We therefore divide estimation into two stages. First, we group variables in our data set into several clusters, e.g. variables related to the industrial sector, variables related to the service sector etc., and extract common factors from each group (see Table A.2). At the second stage of our estimation procedure, we extract a single common factor - the index - from the collection of first-stage factors. Together with the final index, we report the amount of index points each group of first-stage factors contributed. The depth of the information provided by such a decomposition is easily adjustable by the nowcaster and makes it convenient to 'zoom in and out' into the data. This two-stage procedure has two further advantages. First, it removes noise from the underlying variables and thus makes our final index less erratic. Second, it allows to correct for an implicit 'weighting scheme' which is due to the fact that different groups have different sizes. If, for example, two groups of variables are regarded as similarly important by the nowcaster, but one includes only a few series and the second a few hundred. The sheer group size will lead the second group to dominate the first, in that their features will be overrepresented in the common factor. 
This is something a nowcaster might want to preclude. Our first stage allows for such a correction, by limiting the number of common components in each group.

Second, we do not explicitly target a point estimate of GDP. This is for two reasons. On the one hand we still want to leave space for discretionary action by the nowcaster, who has not only the data set of the model but additional 'softer' information at hands. On the other hand, including quarterly GDP as target variable in the model introduces circularity, as GDP would load on GDP and thus nowcast itself.

The paper is structured as follows. In section 2 we briefly discuss the old methodology. Section 3 lays out which series enter our data set. In section 4 we present our methodology and section 5 provides details on the historical performance and other statistical features of the new index. Section 6 concludes.

\section{The DIW Economic Barometer: 2003 until today}

The former edition of the index was based on a set of roughly 60 variables. It contained survey data ( 7 series), data on turnover in different sectors of the economy (9 series), production (16 series), order intake (15 series), financial market data (8 series), and other series, totaling 58 series.

The first edition of the index then employed a standard factor model to filter a latent business cycle index (see Cors and Kuzin, 2003, for details). That is, if we denote by $x_{i, t}$ the $i$-th variable observed in period $t$, where $i=1, \ldots, N$ and $t=1, \ldots, T$ the variable $x_{i, t}$ is decomposed into

$$
x_{i, t}=\boldsymbol{\lambda}_{i}^{\prime} \mathbf{F}_{t}+\epsilon_{i, t}
$$

where $\mathbf{F}_{t}=\left[f_{1, t}, \ldots, f_{r, t}\right]^{\prime}$ is an $r \times 1$ vector of common factors at date $t, \boldsymbol{\lambda}_{i}$ is the $r \times 1$ vector of factor loadings for variable $i$, and $\epsilon_{i, t}$ is an error term.

In contrast to the new edition, the final output was not an index value, but a GDP nowcast that was based on the factor values (see e.g. Stock and Watson, 2006, for a survey of standard procedures to forecast using factor models).

One problem that arises in practice is that many variables $x_{i, t}$ have missing observations, especially at the end of the sample. The former edition of the index employed an ad hoc procedure to handle this. If for example the $i$-th variable $x_{i, T}$ has a missing value in period $T$, the series was shifted one period ahead, i.e. we set $x_{i, t}=x_{i, t-1}$ to reach a balanced data set at the end of the sample. The monthly industrial production figures, for example, are published by the statistical office not until two months later, during which the collection, compilation and processing of relevant information underlying this statistic takes place. Under the former edition, this information was included by forward shifting the latest observations. The advantage of this procedure is the ease with which it can be implemented, but it can be substantially improved by resorting to more advanced statistical methods. To stick to the above example, many survey data from industry, including explicit indications on production, are timely available. Thus, these figures, combined with the information on the link between the survey and industrial production data, yield informative signals on the 


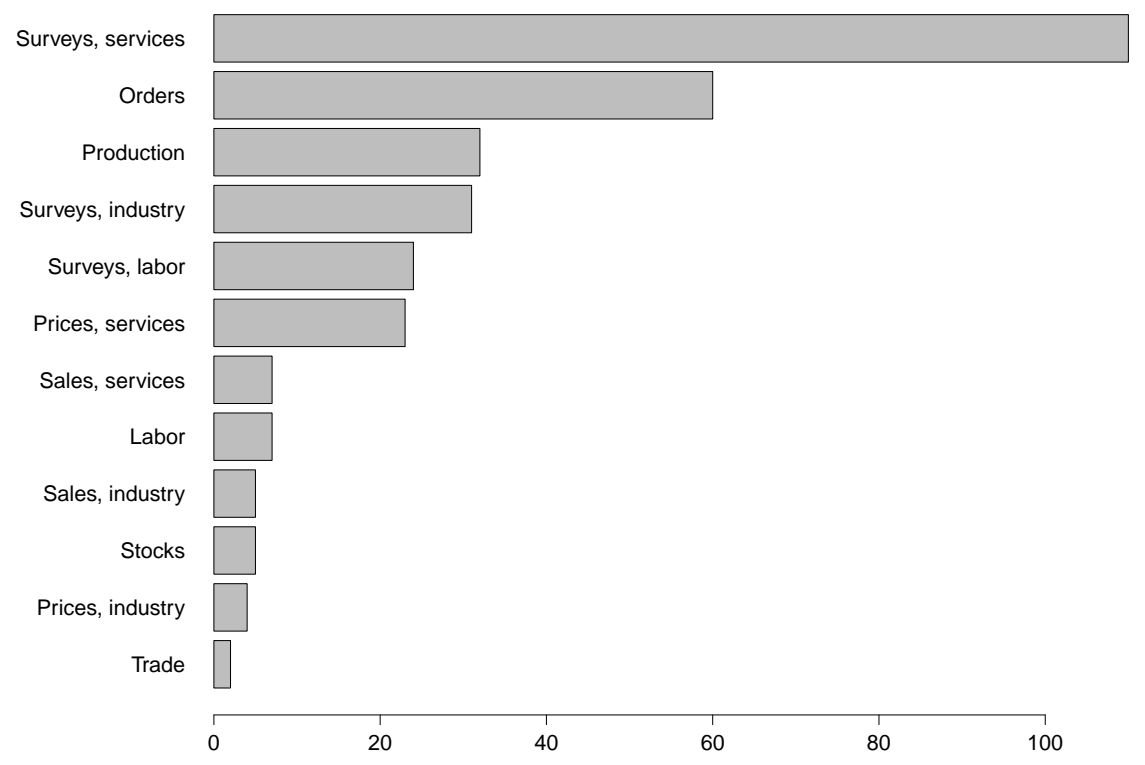

Figure 1: Number of series included in each variable group of the dataset.

missing observations in production. The algorithm applied for the new barometer exploits this information in a first step to infer estimates for the missing values. This procedure is also applied to series, such as retail trade, for which the first observation available is at a later date than for the series with the earliest starting date. This allows extending the sample back to the earliest time period for which sufficient data is available.

\section{Construction of the data set}

The new index not only applies more advanced techniques, it is also based on a substantially enlarged data set. It now includes 311 time series, and in particular extends the scope of relevant information. Whereas the former set had a focus on the supply side and particularly the industry sector, the new edition is based on a broader set of indicators, also covering information for the service sector and the labor market. However, the new editions data set is not only broader, it also is deeper in the sense that more detailed information on the industry sector, which remains the core of the data set, is included. As mentioned above, in order to apply an implicit weighting scheme and at the same time filter out noise, but also for expositional purposes, the data set is grouped into four (sectoral) categories (see Figure 1 for the relative group sizes).

The first contains 134 industry related time series. It assembles production, turnover and order intake series for a variety of industries and adds more timely available survey data among industrial firms. The second group comprises information relevant for the service sector (141 series), such as retail turnover, as well as other turnover data, the number of registrations of new cars, price variables and consumer sentiment indicators as well as a large collection of survey measures from firms in the service sector. The third group is concerned with the labor market. Among 'hard' data 
series such as the employment figures and vacancies, it also contains survey indicators, 31 series in total. The last category contains five series of financial market data, namely major stock and bond indices. Table (A.2) gives an overview of the data set.

\section{Methodology}

We denote by $x_{i, t}$ the $i$-th variable observed in period $t$ and assume that the variable can be decomposed into

$$
x_{i, t}=\lambda_{i}^{\prime} \mathbf{F}_{t}+\epsilon_{i, t}
$$

where $\mathbf{F}_{t}$ is again an $r \times 1$ vector of common factors at date $t, \boldsymbol{\lambda}_{i}$ is the associated $r \times 1$ vector of factor loadings for variable $i$, and $\epsilon_{i, t}$ is an error term. The scalar product between factors and loadings is commonly referred to as common component (it is common among all variables at date $t$ ), whereas $\epsilon_{i, t}$ denotes the idiosyncratic component of variable $i$ (it only affects variable $i$ ). If we define $\mathbf{X}_{t}=\left[x_{i, t}, \ldots, x_{N, t}\right]$ and other variables accordingly, we may write the model more compactly as

$$
\mathbf{X}=\mathbf{F} \boldsymbol{\Lambda}+\boldsymbol{\epsilon},
$$

where $\mathbf{X}=\left[\mathbf{X}_{1}, \ldots, \mathbf{X}_{T}\right]^{\prime}$ is a $T \times N$ matrix, $\mathbf{F}=\left[\mathbf{F}_{1}^{\prime}, \ldots, \mathbf{F}_{T}^{\prime}\right]^{\prime}$ is the $T \times r$ matrix of common factors, $\boldsymbol{\Lambda}$ is the $r \times N$ matrix of factor loadings and $\boldsymbol{\epsilon}$ the $T \times N$ matrix of idiosyncratic errors. The factors, their loadings and the idiosyncratic components are not observable, but have to be estimated from the data. In the parlance of Chamberlain and Rothschild (1983) this model is referred to as approximate factor model. Regarding the properties and features of such a model, first note that the above model assumes a static relationship between the variables in $\mathbf{X}$ and the factors. By static, we mean that only $\mathbf{F}_{t}$ enters the conditional expectation, i.e. $\mathbb{E}\left[\mathbf{X}_{t} \mid \mathbf{F}, \boldsymbol{\Lambda}\right]=\mathbb{E}\left[\mathbf{X}_{t} \mid \mathbf{F}_{t}, \boldsymbol{\Lambda}\right]$. Nonetheless, the static model may be viewed as a representation of a dynamic factor model. That is, it encompasses the case where $\mathbf{F}_{t}=\left[f_{t}, \ldots, f_{t-r+1}\right]$. Hence, while from a dynamic point of view there might be only a single factor, the static model treats it as a $r$ factor model (Stock and Watson, 2006; Bai and Ng, 2002). Intuitively, this may be viewed as a nonparametric approximation to the potentially dynamic factor model. Even though this approach does not model the dynamic properties of the common factors explicitly, (i) the data generating process of the factors becomes irrelevant as $N \rightarrow \infty$ and (ii) the static representation circumvents the issue to choose a lag length for the VARMA process of the factors. As noted in Stock and Watson (2006), we may allow the components of $\epsilon_{t}$ to have an individual stationary autoregressive representation.

With a balanced data set, the factors and their loadings can be estimated using the standard principal component (PC) estimator (see Stock and Watson, 2006). By analogy to a standard regression, the $\mathrm{PC}$ estimator may be considered as the solution to the nonlinear least-squares 
problem

$$
\min _{\mathbf{F}_{1}, \ldots, \mathbf{F}_{T}, \boldsymbol{\Lambda}} \frac{1}{T} \sum_{t=1}^{T}\left(\mathbf{X}_{t}-\mathbf{F}_{t}^{\prime} \boldsymbol{\Lambda}\right)^{\prime}\left(\mathbf{X}_{t}-\mathbf{F}_{t}^{\prime} \mathbf{\Lambda}\right)
$$

It turns out that the solution to this minimization problem can be found by setting the rows of $\hat{\Lambda}$ equal to the $r$ largest eigenvectors of $T^{-1} \mathbf{X}^{\prime} \mathbf{X}$ and the factors equal to the standard least-squares estimate $\mathbf{F}_{t}=\left(\hat{\boldsymbol{\Lambda}}^{\prime} \hat{\boldsymbol{\Lambda}}\right)^{-1} \hat{\boldsymbol{\Lambda}}^{\prime} \mathbf{X}_{T}$. The PC estimator is consistent in $N$ and $T$ for $\mathbf{F}_{t}$ and $\boldsymbol{\Lambda}$ under fairly general conditions (see Stock and Watson, 2006).

\subsection{Handling missing observations and ragged edges}

In practice, we mostly have to work with unbalanced data sets. First, because the series that enter our model have different starting dates and there are a number of missing values at the beginning of the sample. Second, due to the fact that some series' values for a given period $t$ are published earlier than others, there always are ragged edges at the end of our sample. Especially the latter is often troublesome for nowcasting and requires a way to handle missing observations consistently. We follow Schumacher and Breitung (2008) and use the EM algorithm. This algorithm iterates between two steps: (i) estimating the factors and loadings (the E-step) and (ii) filling up missing observations using these estimates (the M-step).

To illustrate how the missing observations are handled, we define $\mathbf{X}_{i}^{\text {obs }}$ as the available observations for variable $i$. That is, we have $T^{o b s} \leq T$ observations for variable $i$, e.g. due to missings at the end of the sample. The vector of available observations $\mathbf{X}_{i}^{\text {obs }}$ is related to the vector $\mathbf{X}_{i}$ defined above through an $T^{o b s} \times T$ aggregator matrix $\mathbf{A}_{i}$

$$
\mathbf{X}_{i}^{o b s}=\mathbf{A}_{i} \mathbf{X}_{i}=\left[\begin{array}{ll}
\mathbf{I}_{T^{o b s}} & \mathbf{0}_{T^{o b s} \times\left(T-T^{o b s}\right)}
\end{array}\right] \mathbf{X}_{i} .
$$

Note that in case no observations are missing, $\mathbf{A}_{i}$ equals the $T$-dimensional identy matrix $\mathbf{I}_{T}$. Given the relationship in equation (4) and an estimate for factors and loadings, we can fill up missing observations for variable $i$ using the state-space form of the factor model (see e.g. Stock and Watson, 2006). For this, we regard equation (4) as the state or measurement equation of a state space model and the $i$-th column of equation (3) as the respective state equation, i.e.

$$
\begin{aligned}
\mathbf{X}_{i}^{o b s} & =\mathbf{A}_{i} \mathbf{X}_{i} \\
\mathbf{X}_{i} & =\mathbf{F} \boldsymbol{\lambda}_{i}+\boldsymbol{\epsilon}_{i} .
\end{aligned}
$$

Then the standard updating equation of the Kalman filter gives us that

$$
\begin{aligned}
\widehat{\mathbf{X}}_{i} & =\mathbb{E}\left[\mathbf{X}_{i} \mid \mathbf{X}_{i}^{o b s}, \mathbf{F}, \boldsymbol{\lambda}_{i}\right] \\
& =\mathbf{F} \boldsymbol{\lambda}_{i}+\mathbf{A}_{i}^{\prime}\left(\mathbf{A}_{i} \mathbf{A}_{i}^{\prime}\right)^{-1}\left[\mathbf{X}_{i}^{o b s}-\mathbf{A}_{i} \mathbf{F} \boldsymbol{\lambda}_{i}\right],
\end{aligned}
$$

where $\boldsymbol{\Lambda}_{i}$ is the $r \times 1$ vector of loadings on variable $i$, i.e. the $i$-th column of $\boldsymbol{\Lambda}$. 
The EM-algorithm thus iterates between the following two steps until convergence

1. E-step: Estimate factors and loadings using the PC estimator based on the matrix $\widehat{\mathbf{X}}$. In the very first iteration use $\mathbf{X}^{\text {obs }}$ with potentially missing values, i.e. extract principal components only based on the available observations.

2. M-step: Fill missing observations in $\mathbf{X}^{o b s}$ using equation (4).

Equipped with this estimation procedure, we construct the final business cycle index as follows. First, we divide the $N=311$ variables in $\mathbf{X}$ into four subgroups: industry and production, service sector, labor market, and stock market. For each of these groups, we compute factors and loadings using the PC estimator described above. Denote the data matrix for subgroup $j=1, \ldots, 4$ by $\mathbf{X}^{(j)}$. We use then use Kaiser-Guttmann rule and set the number of factors in each group equal to the number of the first five eigenvalues of $T^{-1} \mathbf{X}^{(\mathbf{j})^{\prime}} \mathbf{X}^{(\mathbf{j})}$ that exceed one. If we denote by $\mathbf{F}_{t}^{(j)}$ the set of factors extracted from the $j$-th group. The overall monthly DIW Economic Barometer is the PC factor estimate based on $\mathbf{X}_{t}=\left[\mathbf{F}_{\mathbf{t}}^{(\mathbf{1})^{\prime}}, \ldots, \mathbf{F}_{\mathbf{t}}^{(\mathbf{4})^{\prime}}\right]$.

\subsection{Obtaining a nowcast for the current and past quarter}

In order to arrive at a quarterly business cycle index, we employ the aggregation scheme put forward by Mariano and Murasawa $(2003,2010)$. Hence, if we understand $t$ to stand for a point on a monthly grid of index values then we may view quarterly series on this grid as simple skipsampled series, i.e. one that is observable only every third month and missing elsewhere. This is a standard approach to model different frequencies in one model, by regarding it as a missing-value problem. We use a superscript $q$ to denote such a quarterly variable and a superscript $L$ to denote any variable in levels. Then the quarterly business cycle index $\mathbf{F}_{t}^{q, L}$ is given as the average of the monthly values

$$
\begin{aligned}
\mathbf{F}_{t}^{q, L} & =1 / 3\left(\mathbf{F}_{t}^{L}+\mathbf{F}_{t-1}^{L}+\mathbf{F}_{t-2}^{L}\right) \\
\mathbf{F}_{t}^{q, L}-\mathbf{F}_{t-3}^{q, L} & =1 / 3\left(\mathbf{F}_{t}^{L}+\mathbf{F}_{t-1}^{L}+\mathbf{F}_{t-2}^{L}\right)-1 / 3\left(\mathbf{F}_{t-3}^{L}+\mathbf{F}_{t-4}^{L}+\mathbf{F}_{t-5}^{L}\right) \\
& =1 / 3\left(\mathbf{F}_{t}+2 \mathbf{F}_{t-1}+3 \mathbf{F}_{t-2}+2 \mathbf{F}_{t-3}+\mathbf{F}_{t-4}\right) .
\end{aligned}
$$

Hence, to obtain a nowcast, whenever we are in the final month of a quarter and all three values of the monthly business cycle index are available for the current quarter, we can compute the quarterly value using the above scheme. In the previous two months, however, we have to outof-sample forecast the monthly values for $\mathbf{F}_{t+1}$ and possibly also for $\mathbf{F}_{t+2}$. Similarly to obtain a forecast for the quarterly index beyond the current quarter. ${ }^{2}$

To forecast the factors, we employ a standard VAR or AR model where the number of lags is selected using Akaike's information criterion (AIC).

\footnotetext{
${ }^{2}$ Note that this procedure treats the latent index $\mathbf{F}_{t}$ as a flow variable. In principle, the latent index could also be regarded as a stock variable, in which case we would compute the quarterly value as the intra-quarter average of monthly values. The resulting stock-variable version is qualitatively identical to the flow-variable version.
} 

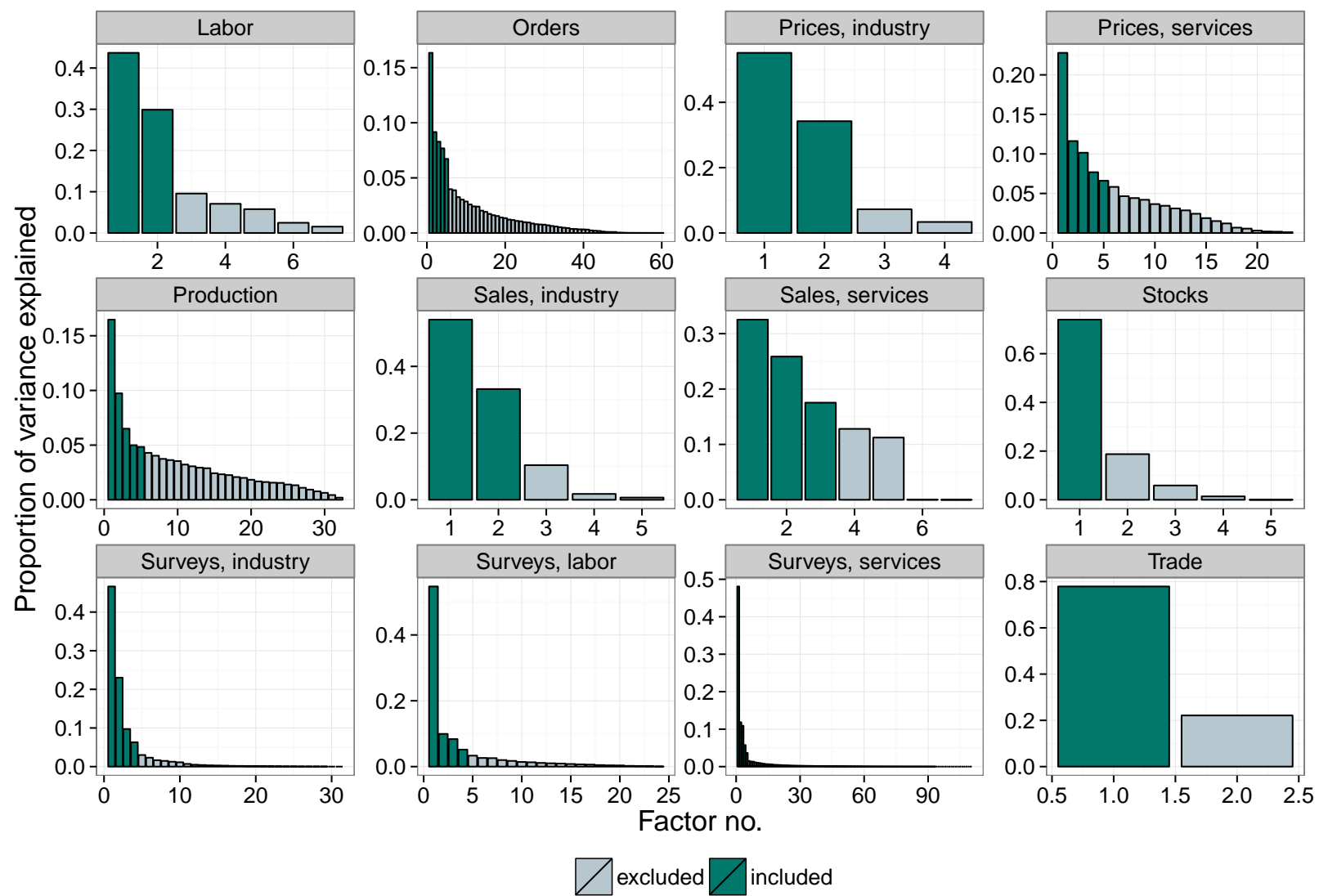

Figure 2: Variance explained by factors for groups of variables (shading indicates whether factor incl. at second stage).

\section{Implementation and descriptives}

In this section, we present several empirical features of our model and the results of a pseudo real-time exercise to assess the now- and forecasting performance for quarterly GDP growth.

As discussed in section 3, the DIW Economic Barometer is based on a large and heterogeneous data set of variables and survey indicators related to economic activity in different sectors of the economy (see table A.2 in the appendix for a detailed list of the data set). It was also mentioned before, that given the diversity of the data set and the fact that group sizes are very unbalanced, an approach is needed which makes sure that the dynamics from each group are appropriately represented in the final index.

We do this by following a two step approach: First, factors for each group of variables are obtained according to the Kaiser-Guttman criterion, but limited to five factors at most. In a second step, we extract the first principal component from the set of factors selected at the first stage. This final factor is the DIW Economic Barometer.

Figure 2 plots the share of variance in each of the variable groups summarized by the respective factors. The factors included in the first step account for about 60 to 95 percent of the variance of 
the respective time series data. Hence, common movements of the series are largely captured, while the noise in the data is already significantly reduced in the first step. Figure 7 in the appendix plots all factors obtained at the group level for completeness.

Given that the resulting common factors on the group level are condensed to a single factor in the second step, the importance of the dynamics of single groups of variables for the movements of the DIW Economic Barometer can be traced by plotting the loadings of the respective intermediate group level factors on the final DIW Economic Barometer. Figure 9 in the appendix reports the loadings and indicates the importance of single groups of variables for the final factor. Note that the loadings are an appropriate measure of importance, since the intermediate group level factors are scaled in each iteration of the EM algorithm. Also note that we report absolute values of the loadings since the signs of the factors are arbitrary.

Clearly, the industry sector data dominates the final DIW Economic Barometer with the first components of industry sector surveys, orders and production indices being the most important intermediate factors driving the final index.

Whereas the EM algorithm used to fill up missing observations in the data and particularly those at the end of the sample is left to update the loadings with every newly available information in the data, the loadings used for the construction of the DIW Economic Barometer are kept constant between the major revisions by the federal statistical office (typically in August of each year). This is done in order to ensure a more stable nowcasting scheme and to be able to clearly attribute any changes in the DIW Economic Barometer to data revisions and newly available data points, but not to changes in the 'interpretation', i.e. the loadings, of the data by the model. ${ }^{3}$

The principal component we extract at the last stage is at a monthly frequency. While this series is fairly erratic compared to its quarterly transformation, our experience is that it can be quite useful to give insights into the latest developments within a quarter. For example, while the quarterly value at the current edge might signal above-average conditions, the monthly series might be on a decline throughout. Compared the official GDP data which is published no earlier than two months after the end of a given quarter, this may be very useful and timely information. Although this is not one of the main purposes of the DIW Economic Barometer as a nowcasting instrument, it allows to potentially spot turning points and trends earlier and more easily as compared to a factor on quarterly frequency.

The aggregation of the factor to quarterly frequency (see Section 4.2) smooths out a large proportion of the volatility of the monthly index. The quarterly factor may then be used for nowcasting German GDP. In order to reduce complexity and make the interpretability more convenient the contributions to the factor from the numerous series in the data set value are plotted by groups or sectors in Figure 3. Table A.2 in the Appendix provides and overview of the categorization, according to which the contributions are grouped to the sectors. Not very surprisingly, the bulk of variation in the factor is due to the dynamics in the industry sector, but the service sector and the labor market also play a significant role. Financial market data only has a minor impact on the

\footnotetext{
${ }^{3}$ Please note that this feature of the implementation has not been implemented in the pseudo real-time nowcasting exercise. However, it is implemented in the day-to-day use of the model for the reasons outlined above.
} 


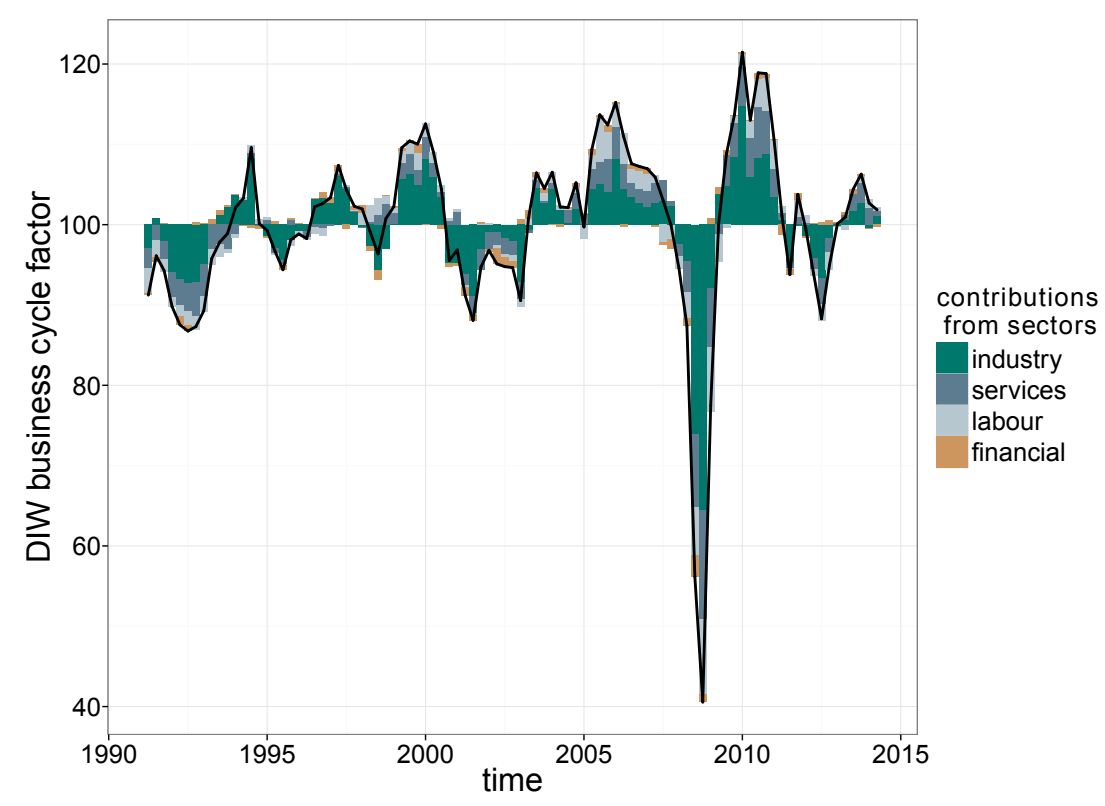

Figure 3: Quarterly DIW Economic Barometer and contributions from sectors

movement of the factor.

For the purpose of reporting in the monthly nowcasting publication of the DIW Berlin, the DIW Konjunkturbarometer, the scaling of the factor is done such that the quarterly factor fluctuates around a value of 100. This highlights that the DIW Economic Barometer is not to be interpreted as a point nowcast by itself but rather as an arbitrarily scaled indicator for the stance of the economy.

Although the construction of the DIW Economic Barometer does not explicitly target a GDP growth rate, there is a significant correlation among the quarterly factor and the quarter on quarter growth rate of German GDP. Figure 4 plots the values of the DIW business cycle index against quarterly GDP growth and provides graphical evidence for the close relation between both. Indeed, the $R^{2}$ from a regression of GDP growth on the index yields an $R^{2}$ of 0.55 and thus a correlation of about 0.74 .

\subsection{Recursive estimation and nowcasting performance}

In order to assess the nowcasting properties of the factor we would ideally make use of vintages of the underlying data. However, this is not possible as many of the included series are not available as vintage data. We take a common shortcut and conduct a pseudo real-time nowcasts for the time period from January 2006 to May 2014. This time period seems recent enough to be relevant for todays nowcasting performance of the model, covers the 2009 recession and can be compared to the vintages of the former DIW nowcasts in order to juxtapose the performance of both. The exercise is pseudo in the sense that data revisions are not taken into account, and that publication lags are introduced according to a static recurring scheme which deletes certain observations before the 


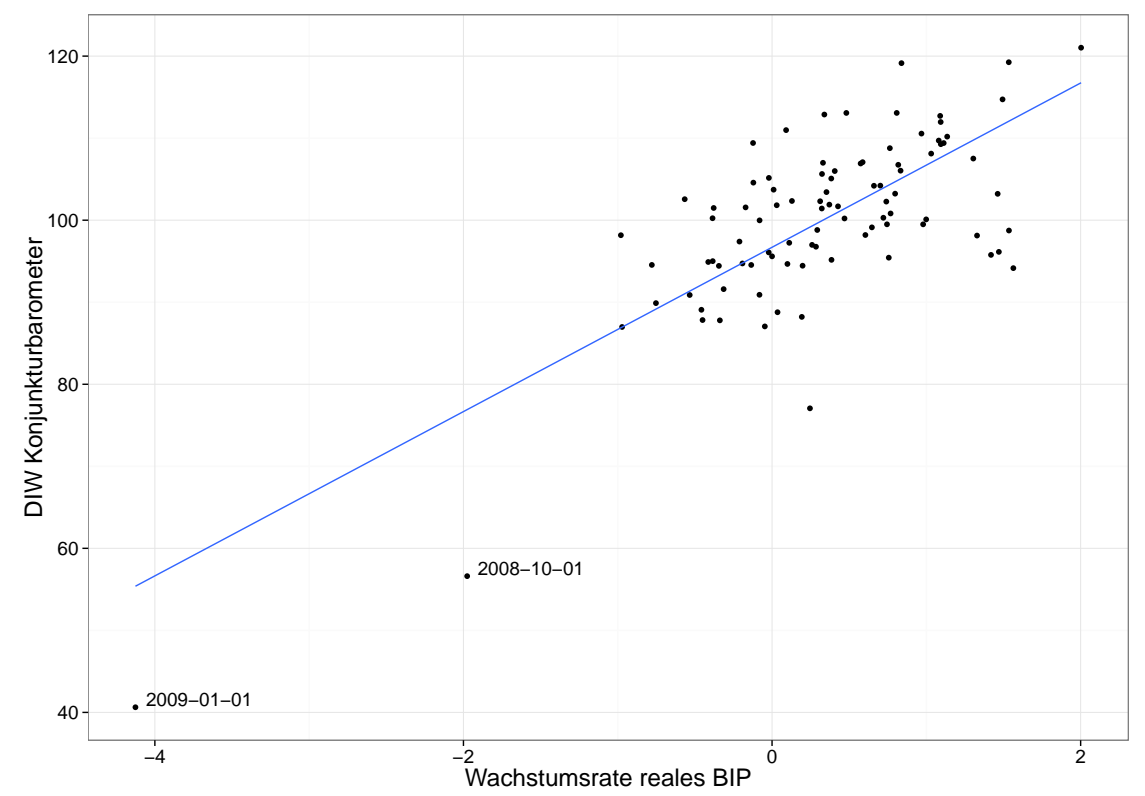

Figure 4: Scatterplot showing the relation between real GDP growth and the DIW Economic Barometer based on data of June 2014.

most recent date. Hence, the edges of the data are artificially ragged according to their publication lag. Note that due to the pseudo character of the exercise revisions of labor market, production, sales and trade data are not taken into account.

Figure 5 plots all factors estimated based on the pseudo real-time data sets for the months from January 2006 up to June 2014. Every color represents pseudo vintages from a different year. Given the potential structural break occurring at the great recession in 2009, the factor is remarkably stable. Based on this exercise the factor even seems to have signaled an upcoming recession from 2008 onward. The observed stability of the factor over time points towards a robust model choice. The baseline specification for the horse race in pseudo real-time is a simple $\mathrm{AR}(\mathrm{p})$ forecast of the quarterly GDP growth rate of the structure

$$
\Delta y_{t}=\alpha+\beta(L) \Delta y_{t}+\epsilon_{t}
$$

where $\Delta y_{t}$ is the quarterly GDP growth rate, $L$ is a lag operator and $\epsilon_{t}$ a white noise error term and the lag length is determined by the Bayesian information criterion. The informational content of the final factor extracted from the about 300 time series is assessed versus a number of competitors, two of them being the ifo business climate index (ifo Geschäftsklimaindex) and the ZEW economic sentiment index (ZEW Konjunkturerwartungen). The three indices are incorporated into to the baseline specification, yielding 


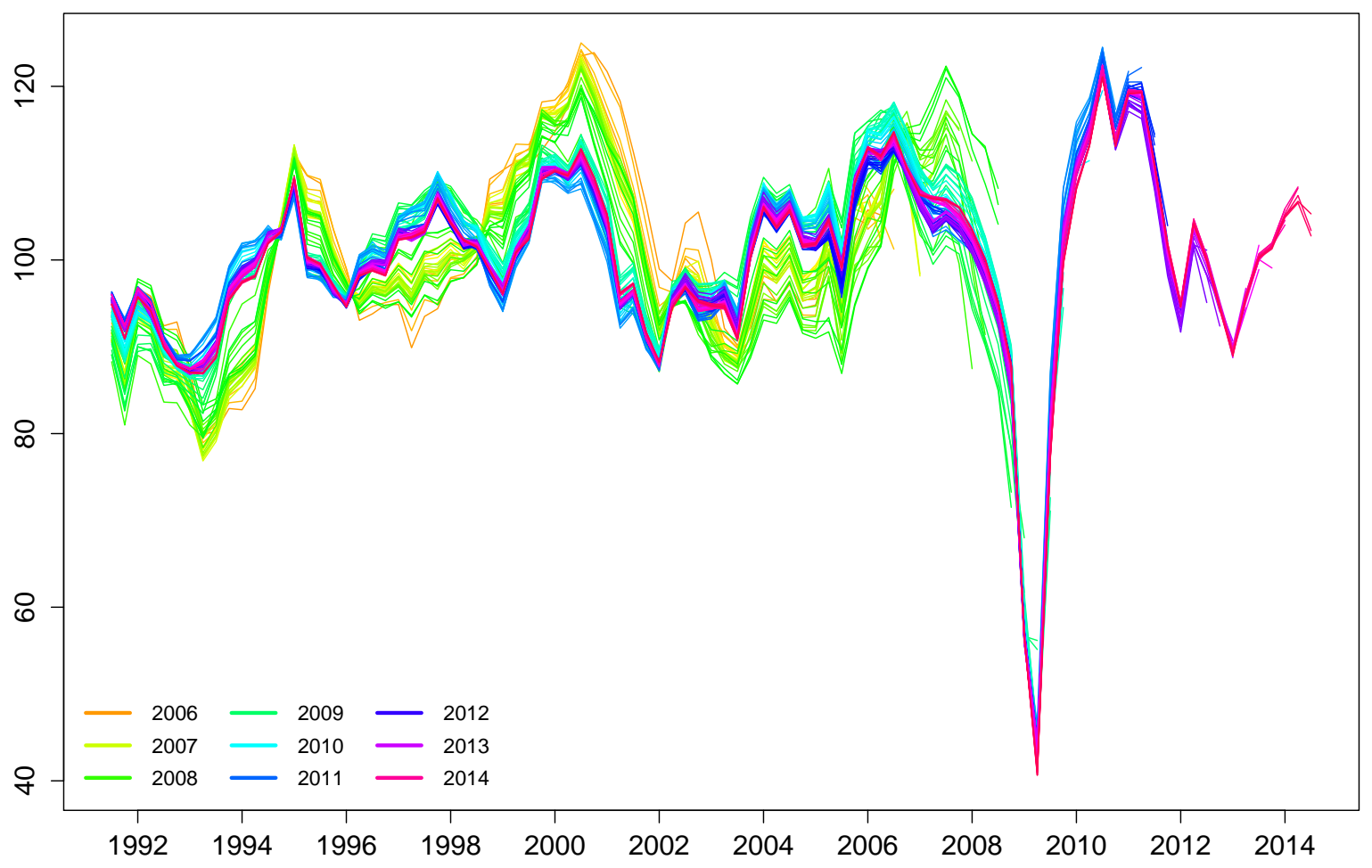

Figure 5: Quarterly factors from pseudo real-time nowcasting exercise. The respective color indicates the year the nowcast was conducted in.

$$
\Delta y_{t}=\alpha+\beta(L) \Delta y_{t}+\gamma x_{t}+\epsilon_{t}
$$

where $x_{t}$ is one of the three indices employed for nowcasting. While the aggregation of the DIW Economic Barometer is conducted as described in detail in Section 4.2, the two competitors on monthly frequency are aggregated by taking averages over all available months within a current quarter. That is, for the first month in a quarter the quarterly value is identical to that of the month, for the second month in a quarter the quarterly value is the mean of the two months' values. Please note, that the data set of the DIW Economic Barometer's new edition includes both indices and hence should also capture the information contained in those.

In addition to the comparison of the nowcasting accuracy of the factor augmented AR(p) with the model augmented by the ifo and ZEW indices, it is also compared to the former edition of the DIW Economic Barometer ${ }^{4}$ and to a naive forecast conducted by a simple random walk.

Whereas in every day nowcasting business those nowcasts could be somewhat adjusted by soft

\footnotetext{
${ }^{4}$ No nowcasting is undertaken for the nowcast predictions of the former DIW Economic Barometer, but rather the vintages of the DIW Economic Barometer are used for comparison.
} 
information available to the nowcaster, this is not possible in the pseudo real-time nowcasting exercise conducted here. Since the federal statistical office announces a GDP estimate for the respective quarter two months after the end of the quarter, we conduct nowcasts for the three months of the quarter and the first month of the following quarter.

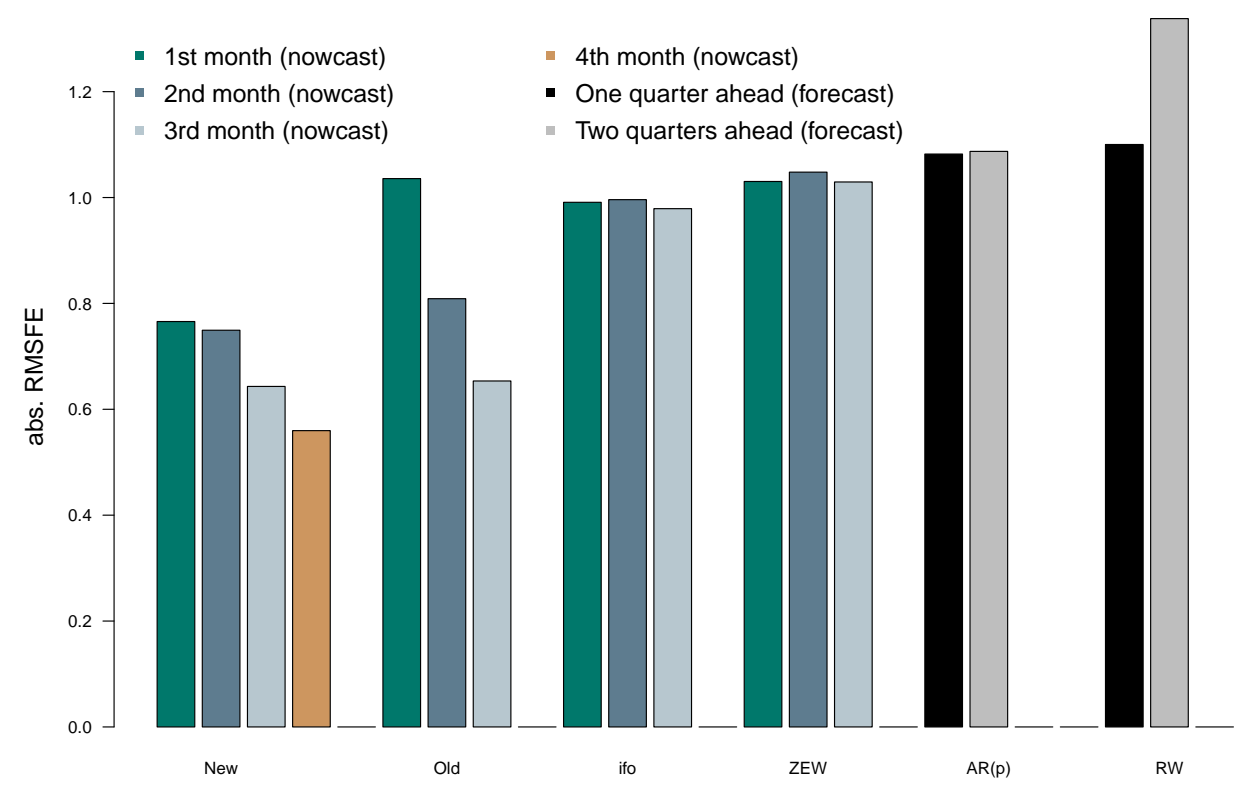

Figure 6: RMSFEs of the new edition compared to several competitors. For the $\operatorname{AR}(p)$ and the random walk model the forecast errors are in terms of quarters ahead, whereas for all other models the bars depict three-month to zero-months ahead errors.

Figure 8 in the appendix plots the nowcast errors for the autoregressive nowcasts augmented with the quarterly DIW Economic Barometer for the first four months after the onset of a quarter. As expected, based on the observations above regarding the correlation between the DIW Economic Barometer and quarterly GDP, the nowcasting model augmented by the factor performs particularly well after the crisis has struck. Also note, that the errors tend to decrease with growing informational content of the data set, i.e. over the four months nowcasts are undertaken for.

As Figure 6 indicates, the comparison of the performance of the factor augmented model with the competitors points towards a strong advantage of the DIW Economic Barometer as compared to the models augmented by single indicator series, the naive random walk and autoregressive forecast ${ }^{5}$. It also outperforms the former DIW Economic Barometer for the first month of a quarter and

\footnotetext{
${ }^{5}$ Given that the model presented here is the only one in the race still gaining information in the first month after the quarter of interest has ended, it is the only one for which a nowcasting RMSFE is reported for that month. The vintages of the former DIW Economic Barometer do not include sufficient information on the nowcasts conducted at this point in time, so no comparison can be undertaken. Except potential revisions there is no gain in information for the ifo and ZEW indices, hence there is no nowcast conducted after the last months index value is reported at the end of the quarter. For the baseline $\operatorname{AR}(\mathrm{p})$ specification and the random walk only quarterly information is at hand, which does not allow a similarly disaggregated nowcast.
} 
produces nowcasts of comparable accuracy in the second and third month of a quarter.

\section{Conclusion}

This paper has laid out the methodological basis of the 2014-version of the DIW Economic Barometer. We extend and overhaul the former version of the DIW Economic Barometer along several dimensions. Firstly, we put forward a factor model that is estimated using the EM-algorithm to take into account missing observations in the data set. Secondly, we deviate from the literature by using a two step factorization procedure. The main advantages of this approach are the option to reweigh groups of variables in order to prevent the final factor to strongly depend on differences in availability and depth of data among different sectors, the possibility to disaggregate the final factor into sectoral contributions for more convenient interpretation and the reduction of noise on both levels of factorization. The resulting factor, the DIW Economic Barometer, provides a remarkably stable, reliable and reasonably precise inference. Results from a pseudo real-time GDP nowcasting exercise show that the new approach is not only conceptually superior, but also produces significantly more accurate nowcasts as compared to a number of competitors, including the former version of the DIW Economic Barometer. In addition inference is stable and reliable, also surrounding extreme events such as the recession in 2009. While from an academic point of view this might seem as a lack of novelty, it is a crucial and very desirable feature in the practice of nowcasting the business cycle. 


\section{A. Appendix}

\section{A.1. Figures}

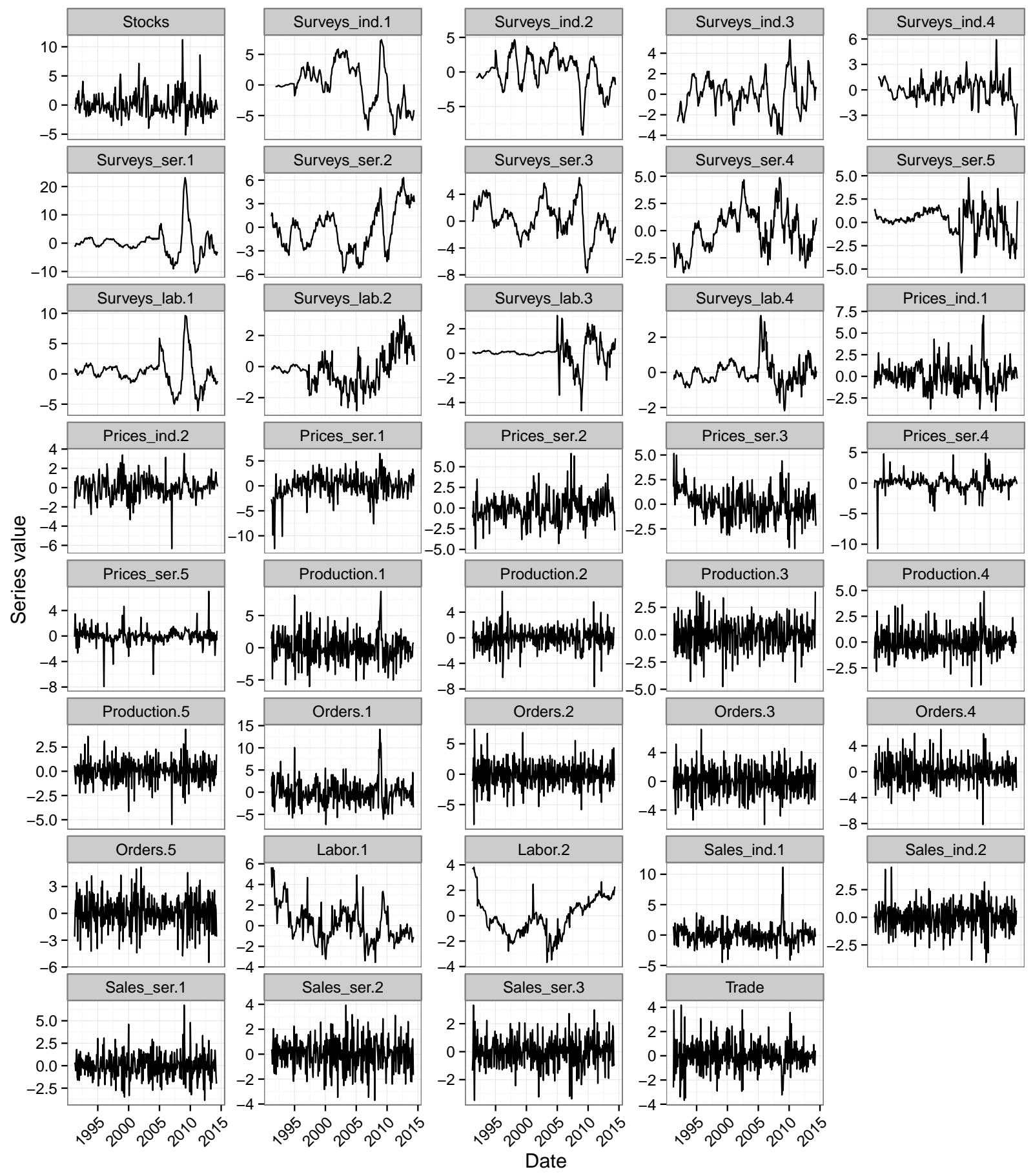

Figure 7: Factors of groups of variables on the intermediate level. The number $i$ following the group name indicates the $i$ th factor extracted from the respected group of variables. 


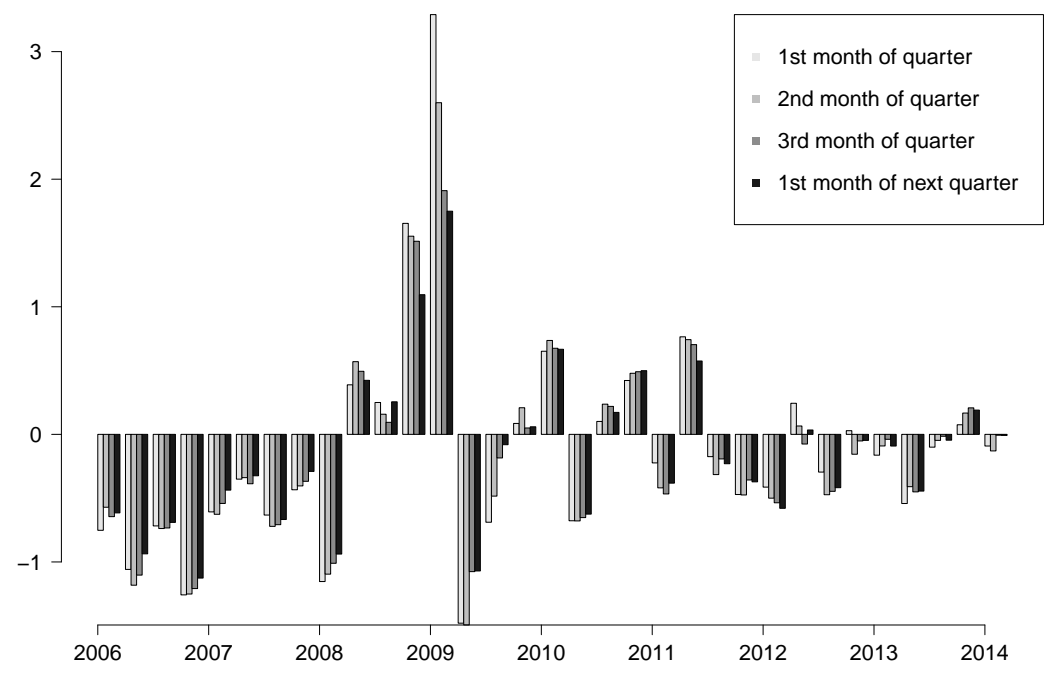

Figure 8: Nowcast errors from the factor model, 1st Quarter 2006 to 1st Quarter 2014.

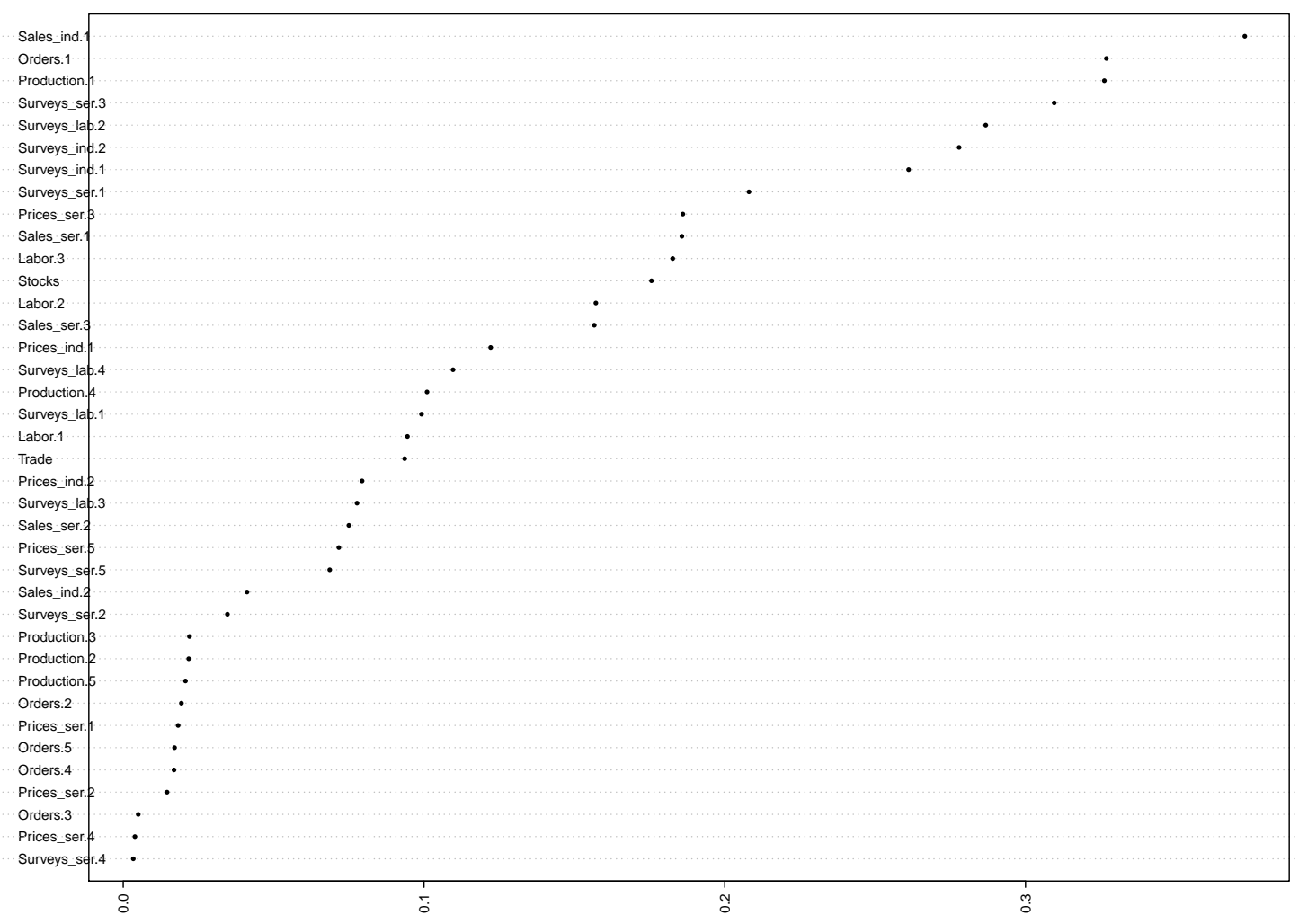

Figure 9: Absolute loadings of group factors on the DIW business cycle factor 


\begin{tabular}{|c|c|c|c|c|}
\hline Typ der Datenreihe(n) & Anzahl & Erste Beobachtung & Quelle & Lags \\
\hline \multicolumn{5}{|c|}{ Kategorie: Industrie (134) } \\
\hline Produktionsindex $^{1}$ & 32 & Jan 1991 & Destatis & 2 \\
\hline Auftragseingangsindex ${ }^{2}$ & 60 & Jan 1991/Jan 2003 & Destatis & 2 \\
\hline Umsatzindex ${ }^{3}$ & 5 & Jan 1991 & Datastream & 2 \\
\hline Ifo Umfrage ${ }^{4}$ & 31 & Jan 1995 & Ifo Institut & 0 \\
\hline Export/Import ${ }^{5}$ & 2 & Jan 1999 & Datastream & 2 \\
\hline Preisindizes $^{6}$ & 2 & Jan 1991 & Datastream & 2 \\
\hline \multicolumn{5}{|c|}{ Kategorie: Dienstleistungen (141) } \\
\hline \multicolumn{5}{|l|}{ Umsatzindex } \\
\hline - Einzelhandel & 1 & Jan 1994 & Bundesbank & 2 \\
\hline - Gastgewerbe & 1 & Jan 1994 & Destatis & 2 \\
\hline - Großhandel & 3 & Jan 1994 & Datastream & 2 \\
\hline - Hotel \& Restaurants & 2 & Jan 1994 & Datastream & 2 \\
\hline Umfrageergebnisse & & & & \\
\hline - Ifo Umfrage 7 & 99 & Jan 2005 & Ifo Institut & 0 \\
\hline - EU Verbrauchervertrauen ${ }^{8}$ & 12 & Jan 1991 & EU Kommission & 1 \\
\hline Preisindex ${ }^{9}$ & 23 & Jan 1991 & Datastream & 1 \\
\hline \multicolumn{5}{|c|}{ Kategorie: Arbeitsmarkt (31) } \\
\hline Arbeitsmarktzahlen ${ }^{10}$ & 7 & \multicolumn{3}{|c|}{ vgl. (10) } \\
\hline Umfrage Arbeitsmarkt $^{11}$ & 24 & \multicolumn{3}{|c|}{ vgl. (11) } \\
\hline \multicolumn{5}{|c|}{ Kategorie: Finanzmarkt (5) } \\
\hline Aktienindex $^{12}$ & 5 & vgl. (12) & Datastream & 0 \\
\hline
\end{tabular}

1. Produktionsindizes werden preis-, kalender- und saisonbereinigt aus folgenden 29 Wirtschaftszweigen verwendet: Hochbau, Tiefbau, Ausbaugewerbe, Kohlenbergbau; Erdöl und Erdgas; Steine und Erden, sonstiger Bergbau; Bergbau und Gewinnung von Steinen; Nahrungsund Futtermittel; Getränkeherstellung; Tabakverarbeitung; Textilien; Bekleidung; Leder, Lederwaren und Schuhe; Holz-, Flecht-, Korb- und Korkwaren (ohne Möbel); Papier, Pappe und Waren daraus; Druckerzeugnisse, Vervielfältigung von Ton-, Bild-- und Datenträgern; Kokerei und Mineralölverarbeitung; chemische Erzeugnisse; pharmazeutische Erzeugnisse; Gummi- und Kunststoffwaren; Glas, -waren, Keramik, Verarbeitung von Steinen und Erden; Metallerzeugung und -bearbeitung; Metallerzeugnisse; Datenverarbeitungs-Geräte, elektronische und optische Erzeugnisse; elektrische Ausrüstungen; Maschinenbau; Kraftwagen und Kraftwagenteile; Sonstiger Fahrzeugbau; Möbel; sonstige Waren; Reparatur und Installation von Maschinen und Ausrüstungen; Energieversorgung.

2. Indizes des Auftragseingangs werden preis-, kalender- und saisonbereinigt aus folgenden zwölf Wirtschaftszweigen verwendet: Textilien; Bekleidung; Papier, Pappe und Waren daraus; chem. Erzeugnisse; pharmazeutischen Erzeugnisse; Metallerzeugung und -bearbeitung; Metallerzeugnisse; DV-Geräten, elektron. u. opt. Erzeugnisse; elektrischen Ausrüstunge; Maschinenbau; Kraftwagen und Kraftwagenteilen; Sonstiger Fahrzeugbau. Es werden jeweils 
der Gesamtindex, der Index der inländischen und der ausländischen Bestellungen genutzt, wobei letzterer nochmals unterteilt wird in Auftragseingänge aus dem Euro- und NichtEuroraum.

3. Umsatzindizes des verarbeitenden Gewerbes werden preis-, kalender- und saisonbereinigt zu folgenden sechs Gütergruppen verwendet: Gesamtindex des verarbeitenden Gewerbes; Konsumgüter; diese zudem aufgeteilt nach langlebigen und kurzlebigen Konsumgütern; Zwischenprodukte; Kapitalgüter.

4. Ifo Umfrage unter Unternehmen des verarbeitenden Gewerbes und des Baugewerbes. Verwendet werden die saisonbereinigten Salden aus positiven und negativen Antworten zu folgenden Kenngrößen: Geschäftsbeurteilung; -erwartungen; und -klima; Produktion gegenüber Vormonat; Produktionspläne; Warenlagerbeurteilung; Nachfrage gegenüber Vormonat; Auftragsbestand gegenüber Vormonat; Auftragsbestandsbeurteilung; Auslandsauftragsbeurteilung; Exporterwartungen; Preise gegenüber Vormonat; Preiserwartungen.

5. Export/Import: nominale, saisonbereinigte Warenaus- bzw. Wareneinfuhren in Mrd EUR.

6. Preisindizes: saisonbereinigte Ausfuhr und Einfuhrpreisindizes sowie Preisindizes für Öl der Marke Brent und Transportkosten.

7. Ifo Umfrage unter Dienstleistern umfasst die folgenden neun Kenngrößen: Geschäftsbeurteilung; -lage; erwartung; -klima; Entwicklung des Umsatzes; Umsatz gegenüber Vorjahr; Umsatzerwartungen; Auftragsbestandsbeurteilung; Preiseerwartungen. Diese werden aus folgenden elf Wirtschaftsbereichen verwendet: Dienstleistungen insgesamt; Gastgewerbe; Landverkehr und Verkehr in Rohrfernleitungen; Lagerei; Erbringung von sonstigen Dienstleistungen für den Verkehr; Erbringung von Dienstleistungen der Informationstechnologien; Rechtsund Steuerberatung; Unternehmensberatung; Architektur- und Ingenieurbüros; technische Tätigkeiten; Reisebüros und -veranstalter.

8. EU Verbrauchervertrauen umfasst saisonbereintige Salden aus positven und negativen Antworten zu folgenden zwölf Kenngrößen: Confidence Indicator; Financial situation over last 12 months; Financial situation over next 12 months; General economic situation over last 12 months; General economic situation over next 12 months; Price trends over last 12 months; Price trends over next 12 months; Major purchases at present; Major purchases over next 12 months; Savings at present; Savings over next 12 months; Statement on financial situation of household.

9. Preisindizes sind saisonbereinigt für den Gesamtindex; den Gesamtindex ohne Energie; und für den Nahrungsmittelindex in das Modell eingegangen. Mangels Verfügbarkeit wurde für folgende 18 Gruppen auf Ursprungswerte zurückgegriffen: Nahrung und nicht-alkoholische Getränke); alkoholische Getränke und Tabak; Kleidung und Schuhe; Wohnraum, Wasser, Elektrizität, Gas und andere Treibstoffe; Möbel, Haushaltswaren und Instandhaltung von Immobilien; Gesundheitswesen; Transport; Kommunikation; Freizeit und Kultur; Bildung; Restaurants und Hotels; verschiedene Güter und Dienstleistungen; Elektrizität; Gas; flüssige Brennstoffe; feste Brennstoffe; Heizenergie; Kraftfahrzeugbrennstoffe; sowie der Vollständigkeit halber auf die Ursprungswerte der o.g. drei Gruppen. 
10. Arbeitsmarktzahlen umfassen folgende Kenngrößen: Von der Bundesbank bezogen: Erwerbstätige in Deutschland (ab Jan 1991, 2 Lags); Arbeitslosigkeit registriert nach $\S 16$ SGB III; Arbeitslosenquote bezogen auf alle zivilen Erwerbspersonen (ab Dez 1991, 1 Lag); Sozialversicherungspflichtig Beschäftigte (ab Jun 1999, 3 Lags); Gemeldete Arbeitsstellen (ab Dez 1999, 1 Lag); Ausschließlich geringfügig entlohnte Beschäftigte (ab Jan 2000, 3 Lags); von der Bundesagentur für Arbeit: Kurzarbeiter (ab Jan 1991, 2 Lags).

11. Umfragen Arbeitsmarkt enthalten 23 Ergebnisse der Ifo Umfrage. Im Einzelnen sind dies die Beschäftigungserwartungen des verarbeitenden Gewerbes sowie die Beschäftigungsentwicklung; -erwartungen; aus den elf unter Punkt (7) aufgeführten Dienstleistungsbereichen; zudem werden die Ergebnisse der Verbraucherumfrage der Europäischen Kommission zur Kenngröße Unemployment expectations over next 12 months verwendet.

Details zu den Quellenangaben

1. Destatis: Statistisches Bundesamt, Genesis-Datenbank

\section{Sonstiges}

1. Aktien- und Rentenindizes (außer Kreditzinsen): Letzter Monatswert aus Tageswerten bis etwa zwei Tage vor Erscheinen des Konjunkturbarometers gemittelt 


\section{References}

Bai, J. and Ng, S. (2002). Determining the number of factors in approximate factor models. Econometrica, 70(1):191-221.

Chamberlain, G. and Rothschild, M. (1983). Arbitrage, factor structure, and mean-variance analysis on large asset markets. Econometrica, 51(5):1281-304.

Cors, A. and Kuzin, V. (2003). An approach for timely estimations of the German GDP. Journal of the German Statistical Society, 87:201-220.

Geweke, J. (1977). The Dynamic Factor Analysis of Economic Time Series. In Aigner, D. and Goldberger, A., editors, Latent Variables in Socio-Economic Models. North-Holland, Amsterdam.

Krengel, R. (1986). Das Deutsche Institut für Wirtschaftsforschung (Institut für Konjunkturforschung) 1925 bis 1979. Duncker \& Humboldt, Berlin.

Mariano, R. and Murasawa, Y. (2003). A new coincident index of business cycles based on monthly and quarterly series. Journal of Applied Econometrics, 18:427-443.

Mariano, R. and Murasawa, Y. (2010). A Coincident Index, Common Factors, and Monthly Real GDP. Oxford Bulletin of Economics and Statistics, 72(1):27-46.

Sargent, T. J. and Sims, C. A. (1977). New methods in business cycle research, volume 1, chapter Business c, pages 145-168. Minneapolis: Federal Reserve Bank of Minneapolis.

Schumacher, C. and Breitung, J. (2008). Real-time forecasting of german gdp based on a large factor model with monthly and quarterly data. International Journal of Forecasting, 24(3):386-398.

Stock, J. and Watson, M. (2006). Forecasting with many Predictors. In Elliott, G., Granger, C., and Timmermann, A., editors, Handbook of Economic Forecasting, volume 1, pages 516-554. Elsevier.

Stock, J. H. and Watson, M. W. (1989a). Macroeconomic forecasting using diffusion indexes. Journal of Business and Economic Statistics, 20(2):147-162.

Stock, J. H. and Watson, M. W. (1989b). New indexes of coincident and leading economic indicators. NBER macroeconomics annual, pages 351-394. 